before settling at Columbia University, where he remained as a professor of government from 1966 until his retirement in 1979 . In the $1950 \mathrm{~s}$, he also served as a senior staff member for the Brookings Institution, where he conducted surveys of foreign affairs, NATO, and the United Nations.

As a graduate instructor, Professor Connery maintained a very focused approach in advising students. He tried to concentrate on producing Ph.D.s who knew their institutions, their history, and their politics, and who engaged in research that had an impact on the world. Professor Connery also served as a model of how to be both a professor and a gentleman. For him, the earned title "professor" was preeminent: "Only use 'doctor' on your checks, or to get a table at a restaurant," he advised. "This is Professor Connery," he announced when he got on the phone.

To those who were close to him, however, Professor Connery acted in a capacity that extended far beyond that of instructor. His titles could have also included those of confessor, patron saint, cheerleader, critic, financial advisor, and closest admirer. Professor Connery was a bachelor and after his mother died had no family. Thus, when a student or researcher studied with Connery, that student became family, and remained so ever after - a fact Connery would reaffirm in many different ways.

Professor Connery served as the president of the Academy of Political Science from 1966 to 1986 , during which time he edited some 40 volumes of its proceedings. His own writings ranged widely over federal, state, and local government issues. Among the many books that he authored, coauthored, and edited is a classic study, Rockefeller of New York: Executive Power in the Statehouse. His Navy experiences prompted him to write Forrestal and the Navy, with Robert G. Albion. This book addressed Forrestal's years in the Navy Department, a time characterized by the rapid expansion of the American Navy and a successful battle to keep the Air Force from taking control of naval air. The interest provoked by his doctoral dissertation, "Governmental Problems in Wildlife Conservation," led to his work as a government consultant in a disagreement between New York and New Jersey over shad fisheries in the Hudson River.

Professor Connery also served as deputy city administrator under Mayor Robert F. Wagner in 1965. He had previously acted as a senior consultant to the State Commission on Governmental Operations of the City of New York and executive secretary of the city's Committee on Modern Zoning. Indeed, city administrators continued to consult with him for some time after his retirement from Columbia in 1976.

Although Robert Connery leaves no immediate survivors, he will live on through his rich legacy of written works, civic achievements, and many friendships. He lived a full life, enjoying good health and mental alertness up until the final months of his ninety years.

Gerald Benjamin State University of New York, New Paltz Demetrios James Caraley Barnard College, Columbia University

\section{C.N. Fortenberry}

Charles Nolan Fortenberry died on May 10, 1998, at the age of 89. He made major contributions to the institutions of the University of Mississippi and Auburn University. Recognition of his impact on faculty and students in those two states over more than three decades of teaching, research, and administration have been acknowledged by the establishment of programs of awards named in his honor at both institutions.

Most of his education took place during the Depression. After completing high school in his native town of Oak Vale, Mississippi, he journeyed north to the University of Mississippi, where he earned both his baccalaureate and masters degrees. This achievement was followed by teaching social science in high schools at Oak Vale and Clinton, Mississippi. From there, he proceeded toward the doctoral degree at the University of Illinois, where he held the post of graduate teaching assistant. While he was at the University of Illinois, he not only obtained a Ph.D. in political science but he also met a candidate for a masters degree in French, Mary Edwards, and married her.

After he earned the Ph.D. in political science, he began his teaching experiences in higher education: Edinburg College as instructor in government, Texas A\&M College as assistant professor, and North Texas State College as assistant professor and then associate professor of government. After serving to the rank of captain in the USA Air Corps, he returned to the University of Mississippi as associate professor and then professor of political science. He eventually rose to the rank of Lieutenant Colonel in the USAF Reserve.

After his colleague Robert B. Highsaw left for the University of Alabama, Nolan Fortenberry was asked to head up the department of research in business and public administration, even though neither was one of his specialties. In 1957 he served as acting dean of the graduate school while the incumbent dean was on sabbatical. In 1958 he became chair of the department of political science, a post he held until 1968.

His tenure as department chair covered the most stormy years of Ole Miss' history, largely involving race relations. He took many personal attacks for his commitment to the U.S. Constitution and his attempts to heal the wounds of the long-building conflict. The forced admission of James Meredith - an African-American, honorably discharged veteran - as a political science major in 1962 intensified these attacks. He also had to face up to the beginning of episodes by a faculty member who had a bipolar disease.

Nolan's colleague, Edward H. Hobbs, moved to Auburn University as dean of arts and sciences in 1967, and in 1968 he asked Nolan to come to Auburn to help get the new department of political science started. Once again, Nolan's administrative acumen was recognized. His philosophy was: "Hire someone good and 
then get out of that person's way." He retired from Auburn University as professor emeritus in 1980.

His primary teaching and research fields were in political theory, the legislative process, and politics and political parties. During his career, he published various monographs and articles in professional journals and coauthored with Dr. Robert B. Highsaw the first textbook on Mississippi state and local government. He also organized and conducted seminars for new members of the legislature and served as a consultant on a number of public policy issues in both Mississippi and Alabama.

At Auburn he created a new department of political science almost from scratch, inheriting a small number of four able faculty members who were transferred from the history department to the new unit in 1968 . By 1980 , when he retired, the department was composed of 20 academic positions, 16 of which were filled with political scientists holding the Ph.D. degree; and there were 341 students majoring in programs offered by the departmentthe largest number of majors, save one, of all the departments in Auburn's School of Arts and Sciences. At that time the department presented five separate curricular offerings: the major in political science through the general curriculum; a criminal justice curriculum; a public administration curriculum; a prehospital and health services administration curriculum; and a pre-law curriculum. A masters program was approved in September 1969. Plans begun in Nolan's administration culminated in the addition of a master of public administration and a Ph.D. in public administration and public policy after his retirement. By the time of his death in 1998 , the department had grown to 28 full-time professional positions, thanks in large part to the remarkable momentum provided by Nolan Fortenberry.

He was preceded in death by his second son, Joseph E. Fortenberry. $\mathrm{He}$ is survived by his wife, Mary Edwards Fortenberry, and his first son, Charles Nolan Fortenberry Jr. of Jackson, Mississippi. He is also sur- vived by Joe's wife, Ashley Doherty Fortenberry, and their daughter, Dorothy Ashley Fortenberry.

Just prior to his death, a former student established the HowertonFortenberry Award in the Study of Government as an endowed fund to honor his two senior professors at the University of Mississippi. Auburn University also established the Fortenberry Scholarship, College of Liberal Arts, at that institution. Donations may be made to either of these funds in his honor or to the Friends of the Library at the University of Mississippi.

Donald S. Vaughan University of Mississippi

\section{David T. Cattell}

David Cattell's retirement from the UCLA's department of political science in 1988, after a service of 36 years, most likely attracted little attention on campus, except from a handful of his close friends. This was because David was one of the most fiercely private persons I have known. Unlike many of his colleagues, he was not prone to engage in lengthy gossip sessions in the faculty center. He was also fiercely independent, as witnessed when, during his progressive illness, he refused his friends' help until he no longer could stand up and walk, and had to use a wheelchair. David's independence, his penchant for privacy, and his inability or unwillingness to suffer fools gladly were further fueled by a certain shyness that many who first met him took for hostility or indifference. This was a pity since, for the few of his real friends, David was truly a uniquely gifted person.

David was born in 1923 in Hinsdale, Illinois. He entered Amherst in 1941 but, like many of his generation, quit college and joined what was then called the U.S. Army Air Corps. In 1943 he was posted to the Fukien Province in China, where for the next three years he was in command of a weather reconnaissance base. He returned to Amherst in 1946 and graduated cum laude the following year with a B.A. in History.

In 1947 David made a decision that was to determine his academic and scholarly career for the next forty years. He enrolled at the newly established Russian Institute at Columbia, which pioneered a new subfield in political science known as Soviet studies, and which became a breeding ground for several generations of specialists in Soviet/Russian area studies. David caught the eye of Philip Mosely, director of the Institute and one of the early giants in the profession, who agreed to sponsor his doctoral dissertation, completed in 1953.

The dissertation, Communism and the Spanish Civil War, published in 1955 by the University of California Press, together with its companion volume, Soviet Diplomacy and the Spanish Civil War (University of California Press, 1957), turned out to be David's most significant scholarly accomplishment. Based on extensive archival research in England, Holland, and Spain, both books became minor classics and obligatory reading for graduate students and fellow scholars alike. Translated into Italian, they were reprinted by the Johnson Reprint Corporation in 1969.

David joined UCLA's department of political science in 1952 as an instructor, reaching full professor in 1966. He soon developed into one of the most effective undergraduate and graduate teachers in the department, as testified by unsolicited evaluations, especially from his graduate students who commented favorably on his commitment to excellence, the time he devoted to advising his students, and to his insistence on bringing out the best among his students. Many of the Ph.D. students he sponsored ended up at various universities around the country; one of them, Professor Edward Gonzalez, retired in 1994 after teaching political science for 28 years at UCLA. David also taught as an exchange professor in Leningrad (1966), Kampala, Uganda (1967), and Rio de Janeiro (1970).

From the outset, David devoted much effort and energy to university affairs, at both the campus and statewide levels. The highly laudatory letters from the President's Office in Berkeley and from chairmen of various Academic Senate 